University of Nebraska - Lincoln

DigitalCommons@University of Nebraska - Lincoln

Faculty Publications -- Department of English

English, Department of

1958

Satire and Symbolism in Bleak House

Louis Crompton

University of Nebraska - Lincoln

Follow this and additional works at: https://digitalcommons.unl.edu/englishfacpubs

Part of the English Language and Literature Commons

Crompton, Louis, "Satire and Symbolism in Bleak House" (1958). Faculty Publications -- Department of English. 63.

https://digitalcommons.unl.edu/englishfacpubs/63

This Article is brought to you for free and open access by the English, Department of at DigitalCommons@University of Nebraska - Lincoln. It has been accepted for inclusion in Faculty Publications -- Department of English by an authorized administrator of DigitalCommons@University of Nebraska - Lincoln. 


\title{
Satire
}

\section{and Symbolism in Bleak House}

\author{
LOUIS CROMPTON
}

\section{I} portrayed with a power and vividness elsewhere unmatched in English fiction. Decaying slums with their filthy tenants, a sedately proud but hopelessly outmoded aristocracy, lawyers and clients lost in a fog of legal obfuscation, a confused and silly parliament engaged in a perpetual game of musical chairs; the magnitude of these symptoms of social distress is impressive, and equaled only by the completeness of the failure of those in power to deal with them. Whatever the dramatic weaknesses and confusions of the book, this satirical image of society is communicated to the reader with unforgettable brilliance, chiefly through a wealth of descriptive detail that is perhaps subtler and more suggestive than in any other novel by Dickens. The purpose of this essay is first to relate this social satire to what I believe to be the central theme of Bleak House and then to show how the incidental detail, functioning through symbolism and fantasy, sharpens, develops, and intensifies the novel's satiric meaning.

Dramatically, Bleak House is a tragicomedy in which the tragic situations are of a peculiarly distressing sort. A cheerful and generous boy is turned into an embittered neurotic through his involvement in a Chancery lawsuit. Another suitor, Mr. Gridley,

Louis Crompton is an assistant professor of English at the University of Nebraska. 
dies in penury and despair, harassed by the law on his very deathbed. Jo, the pathetic little crossing sweeper, falls victim to the smallpox bred in the plague-stricken tenement he lives in. Esther Summerson, a young girl of obscure origins, discovers that her mother is debarred by social conventions from ever recognizing her. The book is permeated by an atmosphere of almost morbid depression, as far removed as possible from the cheerful vagaries of Pickwick or the sentimental optimism of A Christmas Carol.

The desire for money, for enhanced social position, or, occasionally, for moral self-aggrandizement appear to be the ostensible and immediate causes of this evil, though a great part of the horror lies in the mechanical way in which these ends are pursued. This is not a novel about demoniacs mad for power, after the fashion of Dostoievsky's The Devils. Honoria Dedlock's rise to social eminence is, significantly, a thing of the past by the time the novel opens. Instead, those in control of society are shown as bored and weary, dead emotionally as well as morally and politically. The frenzy and madness are found only in their victims-Richard Carstone, Gridley, Miss Flite, and George Rouncewell. Those in whom power is vested remain persistently remote and insensitive: their sins are not sins of passion but sins of neglect. Dickens's triumph is to render intelligible and vivid the consequences of this social impasse.

Where does Dickens place the ultimate blame for the creation of this nightmare world? One is at first inclined to say that its cause is an antediluvian social system cherished by the aristocracy as a bulwark for its privileges. But this turns out not to be the case. Dickens makes it clear, as the novel progresses, that the aristocracy by itself is completely helpless; it has fallen into the hands of its middle-class servants who can bend even so formidable a character as Lady Dedlock to their own purposes. When, in a political crisis, the Tories lose the election to Rouncewell and the reform party, Sir Leicester Dedlock is merely dazed by the result; he is incapable of grasping the historical significance of the de- 
velopment. The real power behind the scenes is bourgeois in origin: the Dedlock fortunes lie entirely in the hands of Mr. Tulkinghorn, the family lawyer.

But if the aristocracy is politically ineffectual, its social prestige still has a devastating force psychologically; it is capable of freezing Esther's naturally passionate and tempestuous mother into a mold of chilly aloofness. One thinks of Matthew Arnold's remark that no Englishwoman of the Victorian middle classes was capable of acting naturally. The paradox lies in the fact that the hauteur manifested by Lady Dedlock is, in its peculiar form and intensity, a middle-class phenomenon born of the fear that emotional forthrightness would, in the eyes of the aristocracy, identify a person with the vulgar masses. To dramatize this condition, Dickens contrasts Lady Dedlock's relationship with Esther with that of the housekeeper, Mrs. Rouncewell, to her long-lost son George. When, in one of the climactic scenes of the novel, Mrs. Rouncewell, erroneously believing Lady Dedlock to be implicated in the murder of which her son is accused, asks her to clear him of suspicion, Lady Dedlock can find no adequate emotional response to the situation: she has been "so long accustomed to suppress emotion, and keep down reality; so long schooled for her own purposes, in that destructive school which shuts up the natural feelings of the heart...." As "madness" of the heart-the desperate pursuit of the wrong object-infects Pip, Estella, Miss Havisham, and Magwitch in Great Expectations, so a contrasting motif runs through Bleak House, but in this case the debilitating influence is a peculiar emotional deadness, the inabiltiy to enter vicariously into the imaginations of others. In the one book the moral imagination works fantastically to its own hurt and destruction, in the second, it is dead and unexercised. It is significant that even the minor characters suppress the word "heart" in phrases in which it would naturally occur. Mr. Turveydrop groans that the marriage of the son who has hitherto been slaving menially to support him is "an arrow launched at my brain," and Mr. Guppy, regretting the 
failure of his farcically legalistic wooing of Esther, complains to his friend Jobling that "there are chords of the human mind."

The peculiarly middle-class nature of this malady is made clear when we see Sir Leicester himself reacting to a domestic crisis, namely the discovery of his wife's dishonor. Persistently pompous and absurd where questions of precedent or privilege are involved, he behaves at this point in a chivalrous and humane manner. By contrast, Mr. Rouncewell, who at the beginning of the novel, we expect to fill the role of revolutionary hero-his son's name ${ }^{1}$ and his own firm but dignified refusal to enter into his prescribed role of family retainer in the Dedlock household seem at first to be clear clues to such a development-gradually hardens into a stiffnecked bourgeois. Mr. Tulkinghorn warns Lady Dedlock that Rouncewell's party will scorn her if they learn that Esther is her illegitimate daughter and can be expected to make moral and political capital out of the discovery. In fact, Tulkinghorn sees to the very depths of the situation: his chief reason for keeping Lady Dedlock's secret is that he feels he cannot trust Sir Leicester to be as calculatingly jealous of aristocratic honor as he is himself. $\mathrm{He}$ fears that Sir Leicester may forgive his wife and the thought of the social consequences of this forgiveness terrifies him. Again Dickens's analysis of the relationship of bourgeois and aristocrat agrees with that in Arnold's Culture and Anarchy. The upper classes may be impervious to new ideas, but they are above pettiness and meanness. One recalls that even the authors of the Communist Manifesto, who could scarcely be accused of a bias in favour of feudalism, saw the aristocracy as in certain respects more humanely attractive than the middle class that was supplanting them.

How does Dickens deal with these social relationships in his novel? In part, like any novelist, he explores them dramatically; any full consideration of Dickens's achievement, however, must

\footnotetext{
1 "Watt" Rouncewell, a name that is meant to link the Peasants' Revolt (Wat Tyler) and the Industrial Revolution (James Watt). It is part of the irony of the novel that Sir Leicester, in suspecting Mr. Rouncewell of "Wat Tylerish" tendencies, is unaware that the nature of the threat to upper-class power is any different from what it was in the fourteenth century.
} 
take into account the two literary devices by which Dickens illuminates and vivifies his judgments of Victorian society: his symbolism and his satiric exaggeration. The following is not an exhaustive study of the use of these devices in Bleak House, but merely an attempt to indicate in how subtle and complex a manner Dickens succeeds in adapting them to his material.

Dickens directs his attention in the novel to four main groups of characters. The first are those who, either by virtue of their social status or psychological orientation, are connected with the world of fashionable elegance. These include Sir Leicester and Volumnia Dedlock, Mr. Turveydrop, and Harold Skimpole. The second are the legal and commercial parasites: Mr. Tulkinghorn, Mr. Vholes, and Grandfather Smallweed. The third group pretend to social or religious benevolence but are actually indifferent to other people and merely concerned with exercising their own will to power. Mrs. Jellyby, Mrs. Pardiggle, and the Rev. Mr. Chadband fall into this category. Each group is in turn identified with a set of symbols relating to its social health or corruption. These values are epitomized respectively by images of vitality and abundance, and by stuntedness, sterility, and decay.

We may begin by considering a fourth group, the victims of social oppression and their champions: Esther, George Rouncewell, the Bagnets, John Jarndyce, and Boythorn. All of these characters are associated with some quality of innocence and have as their symbolic background a pastoral landscape threatened by the encroachment of the social desert. Esther, for instance, is usually dismissed as a particularly cloying example of Dickens's "good" women, whose manner is affectedly naive. Critics, in visiting their just wrath on Dickens for giving Esther these exasperating traits, have, however, failed to note how adequately, apart from them, she fills her proper place in the novel. Symbolically, she stands for domestic order in a world in which this value has been violated or ignored: she restores order to the Jellyby and Turveydrop households (the latter name suggests the inverted values in the two 
homes where the parents exploit instead of nurturing their children), she corrects as best she can the clumsy offenses against human dignity and privacy that spring from Mrs. Pardiggle's officious charity, and she reestablishes happiness at Bleak House. Her name-"Summerson"-is indicative of her restorative powers. In the foggy scene with which the book opens, Dickens remarks that the world seems to have "gone into mourning ... for the death of the sun." This faculty is symbolically related to the landscape she inhabits; both the old and the new Bleak House are surrounded by "beds and flowers" that are her especial care. The fertility motif is further exemplified in the school she attends as a girl at the beginning of the novel, which is called "Greenleaf."

Lawrence Boythorn, like Esther, stands for natural affection and an unperverted sensibility. In addition, he shows some of the highspirited cantankerousness of Walter Savage Landor, on whom Dickens modeled the character. Landor was expelled from Oxford for having fired a bullet through the window of a Tory: Boythorn is likewise a radical in politics, noted for having beaten the bullies at school and having defied overbearing authority in the army. His quarrels with Sir Leicester challenge aristocratic privilege; his large size links him with trooper George as one of the book's good giants. He is associated with ripe maturity as Esther is with the nurturing powers of nature. The description of his house in Lincolnshire contrasts vividly with the urban squalor of TomAll-Alone's and the dead pastoral of Chesney Wold:

He lived in a pretty house, formerly the Parsonage-house, with a lawn in front, a bright flower-garden at the side, and a well-stocked orchard and kitchen-garden in the rear, enclosed by a venerable wall that had of itself a ripened, ruddy look. But, indeed, everything about the place wore an aspect of maturity and abundance. The old lime-tree walk was like green cloisters, the very shadows of the cherry-trees and apple-trees were heavy with fruit, the gooseberry-bushes were so laden that their branches arched and rested on the earth, the strawberries and the raspberries grew in like profusion, and the peaches basked by the hundred on the wall. Tumbled about among the spread nets and the glass frames sparkling and winking in the sun, there were such heaps of drooping pods, and marrows, and cucumbers, that every foot of 
ground appeared a vegetable treasury, while the smell of sweet herbs and all kinds of wholesome growth (to say nothing of the neighboring meadows where the hay was carrying) made the whole air a great nosegay. Such stillness and composure reigned within the orderly precincts of the old red wall, that even the feathers hung in garlands to scare the birds hardly stirred; and the wall had such a ripening influence that where, here and there high up, a disused nail and scrap of list still clung to it, it was easy to fancy that they had mellowed with the changing seasons, and that they had rusted and decayed according to the common fate.

The Rouncewell-Bagnet circle, the other group of decent, simple people in Bleak House, is symbolically related to this vitality and freshness through the "greens" that Mrs. Bagnet is constantly washing and through the nickname her husband bears-lignum vitae, "tree of life."

The elementary springs of life in England, Dickens implies, are in danger both from aristocratic and middle-class power. The threat from the former is stultification: the aristocratic world is characterized by images of rain and stagnant water, fading lights, sleeping animals, and decaying trees. Dickens relates Chesney Wold, Sir Leicester's estate, to the story of Sleeping Beauty; even the animals in its stables seem to have dozed off as if affected by some magic spell. The legal and commercial world is, as we might expect, represented in a still more sinister fashion; the corresponding associations are with fog and soot, darkness, vampirism, stalking animals of prey, and a pastoral landscape pillaged for commercial ends. Grandfather Smallweed, Dickens notes, has had so little acquaintance with imaginative literature that he has never heard of Jack the Giant Killer. Dickens does not press the point, but it comes as a powerful ironic shock to realize that the "Jacks" of this story are not the young heroes but aged pygmy parasites like Grandfather Smallweed, and the giants are their victims, the strapping healthy innocents like trooper George.

Dickens elaborates on many of these details in a subtle and richly suggestive fashion. For example, consider the bird symbolism which is used to call attention to the parasitism of the legal and 
commercial figures. Dickens introduces two kinds of birds into the novel: the song-birds which stand for innocence and happiness (Miss Flite's birds and Boythorn's canary), and the crows and rooks which are associated with the aristocracy and the law. Chesney Wold, in particular, is surrounded by an immense rookery. Dickens, with what seems like a merely conventional figure of speech invites the reader, at the beginning of the second chapter, to look in at Chesney Wold: "It is not so unlike the Court of Chancery, but that one may pass from the one scene to the other, as the crow flies." It is only later that we come to identify this passage to-and-fro from London to Lincolnshire with Mr. Tulkinghorn whose black clothes, which reflect no light, make him look like "a larger species of rook."

The cumulative effect of these macabre suggestions is powerful and chilling. In introducing them Dickens may possibly have been influenced by a literary work which he had frequently in mind in writing the novel: Macbeth. There are several verbal echoes of the play. Mr. Turveydrop remarks dolefully that the world is falling into the "sear and yellow leaf," the screams of the epileptic servant girl "murder sleep," and a good deal of the grotesque imagery of the story seems to have been suggested by Macbeth's lines:

Light thickens and the crow makes way to the rooky wood, Good things of day begin to droop and drowse

Whiles night's black agents to their preys do rouse.

Certainly these lines provide a striking commentary on Dickens's meaning; throughout the latter part of Bleak House he dwells more and more on the darkness of the lawyers' chambers in contrast to the rural sunshine, and the clients come eventually to be referred to as "prey."

Dickens in his novels distinguishes carefully between the attitudes adopted by the middle and upper classes in the face of popular discontent. The former appeal to the rationalizations of the utilitarian economists; Dickens demonstrates this in Hard Times where he dramatizes the relationship of Gradgrind and Bounderby. 
In Bleak House he is concerned with the psychology of the aristocratic attitude, a frame of mind which he calls "dandyism." The heyday of dandyism in dress had, of course, been the Regency period when the aristocracy, reveling in its triumph over Napoleon and the forces that inspired the French Revolution, had taken its cue from the Prince Regent and Beau Brummel. In using dandyism as a symbol of the indifference of fashionable society to social misery, Dickens may well have been influenced by chapter ten ("The Dandaical Body") of Sartor Resartus in which Carlyle sets Regency fops against the hungry Irish for satirical purposes. Dickens ironically laments the fact that, in the context of the 'forties and 'fifties, Regency styles seem, despite relics like Mr. Turveydrop who had once won Prince George's approbation at Brighton, hopelessly out of date:

There is no King George the Fourth now (more's the pity!) to set the dandy fashion; there are no clear-starched jack-towel neckcloths, no shortwaisted coats, no false calves, no stays. There are no caricatures now of effeminate Exquisites so arrayed, swooning in opera boxes with excess of delight, and being revived by other dainty creatures, poking long-necked scent-bottles at their noses.

Instead the new dandyism finds expression in ultra-conservative views on politics and religion, and in opposition to sentiment and realism in art:

There are also ladies and gentlemen of another fashion, not so new, but very elegant, who have agreed to put a smooth glaze on the world, and to keep down all its realities. For whom everything must be languid and pretty. Who have found out the perpetual stoppage. Who are to rejoice at nothing, and be sorry for nothing. Who are not to be disturbed by ideas. On whom even the Fine Arts, attending in powder and walking backward like the Lord Chamberlain, must array themselves in the milliners' and tailors' patterns of past generations, and be particularly careful not to be in earnest, or to receive any impress from the moving age.

Dickens's satire in Bleak House has frequently the heavy, almost bludgeoning irony of a pamphlet by Carlyle. Where it succeeds it does so by virtue of its sweeping energy and sharp wit; where it fails it is because of its overly elaborate rhetoric. In dealing with the 
foibles of the aristocracy, however, Dickens can refine his instrument to a rapier keenness, as in his treatment of Volumnia Dedlock. Volumnia" is a "young lady of sixty" who wears a large antiquated necklace suggestive of "pilfered birds' eggs." In her conversations with Sir Leicester she evinces sympathetic horror at the presumptuousness of the lower orders, but she is in actuality as blind to the true state of society as Marie Antoinette in the Trianon. With satirical finesse worthy of Pope, Dickens gives us a last glimpse of her and the aristocracy she epitomizes before "darkness" finally descends on Chesney Wold at the end of the novel. She is the heroine of The Rape of the Lock more than a century out of date, enjoying a Struldbruggian old age:

The only great occasions for Volumnia, in this changed aspect of the place in Lincolnshire, are those occasions, rare and widely-separated, when something is to be done for the county, for the country, in the way of gracing a public ball. Then, indeed, does the tuckered sylph come out in fairy form, and proceed with joy under cousinly escort to the exhausted old assemblyroom, fourteen heavy miles off...... Then, indeed, does she captivate all hearts by her condescension, by her girlish vivacity, and by her skipping about as in the days when the hideous old general with the mouth too full of teeth, had not cut one of them at two guineas each. Then does she twirl and twine, a pastoral nymph of good family, through the mazes of the dance. Then do the swains appear with tea, with lemonade, with sandwiches, with homage. Then is she kind and cruel, stately and unassuming, various, beautifully wilful. Then is there a singular kind of parallel between her and the little glass chandeliers of another age, embellishing that assembly-room; which, with their meagre stems, their spare little drops, their disappointing knobs where no drops are, their bare little stalks from which both knobs and drops have departed, and their little feeble prismatic twinkling, all seem Volumnias.

This portrait is reminiscent of the devastating pictures of superannuated winsomeness in Pope's "Of the Characters of Women." Where Dickens differs from Pope is in his use of the type to satirize a whole social class, and in his symbolism. The "bare little stalks" echo the sterility theme in the novel and relate the "pastoral nymph" to the pastoral landscape.

\footnotetext{
${ }^{2} \mathrm{Her}$ name suggests aristocratic pride. Cf. Mrs. Sparsits' "Coriolanian" profile in Hard Times.
} 
Searching for a symbolism that will illuminate these social relationships, Dickens extends this last image by exploiting one of the oldest forms of literary satire: the use of pastoral conventions to mock a corrupt society. In Bleak House we have the literary conventions of "The Shepherds' Calendar" and "Lycidas" applied to the satire of Victorian society. How Dickens happened to hit upon this traditional mode of satire for his novel remains obscure. Perhaps he was struck by the pastoral reminiscences in London place names. He recalls, for instance, that Lincoln Inn "Fields" must at one time have designated open countryside; at another point of the novel one of the minor characters remembers the tradition that a "brook as clear as crystal" once ran down Holborn. Now, however, the district of the law courts is seen as fantastically transformed from its first pastoral origins: "the sheep are all made into parchment, the goats into wigs, and the pasture into chaff." To communicate his sense of how a mechanical and insensitive legal machinery has devastated country estates in the name of justice, John Jaryndyce parodies the endless proceedings in Chancery as the most "infernal country dance of costs and fees and nonsense and corruption as was ever dreamt of in the wildest visions of a Witch's Sabbath." This image of the compulsive dance is one of the three central symbols of the pastoral satire in the novel; the other two are the blighted landscape and the sinister shepherd.

The traditional literary use of pastoral satire has most often been the exposure of a corrupt clergy. Dickens's portrait of the Rev. Mr. Chadband conforms to one kind of anti-clerical satire: he is represented not as feeding his flock, but as being fed by them. Dickens gives him the humorous epithet of the "Oil Mill," wittily implying that he spends his time converting greasy meals into ecclesiastical unction. (Milton's epithet "Blind mouths" applied to the placeseeking divines in "Lycidas" comes to mind here.) Chadband ultimately achieves the height of clerical hypocrisy by employing conventional pastoral terms-“corn, wine, and oil"-when he is in fact demanding blackmail from Sir Leicester. 
But Dickens is only very little interested in religion in Bleak House. He is more concerned with the class of men whose normal function in society is to mediate between the individual and some social need, legal or commercial. This class is largely represented as a gallery of monsters: the subhuman Smallweed who fastens on his victims like some noxious insect; the haughty Tulkinghorn jealously gleaning the spoils of aristocratic privilege; Mr. Vholes. Finally, there is Mr. Guppy, who is distinguished from the other lawyers in that he does not possess power but merely aspires to it. As a comic character he is the supreme achievement of the book. $\mathrm{He}$ is a legal automaton bedeviled by human emotions which only make him look pathetic and ridiculous. Unlike most of the other people officially connected with the law, he is not a natural-born monster, but a modest and likable man undergoing metamorphosis by professional pressures, and too blind to see the mean and absurd figure he cuts. His three proposal scenes with Esther punctuate the novel at carefully spaced intervals, and are masterpieces of dramatic humor. As love scenes in which the language of sentiment has been turned into legal jargon, they contain the meaning of the novel in small.

It is not, in fact, the clergy but the lawyers who are identified with the traditional symbol for the corrupt functionary in pastoral: the shepherd who plunders his own flock. After drawing ironic parallels between Lincoln Inn Fields and the unspoiled countryside, Dickens attacks the cupidity of the human beings who inhabit this material and moral wasteland:

In these fields of Mr. Tulkinghorn's inhabiting, ... the shepherds play on Chancery pipes that have no stop, and keep their sheep in the fold by hook and by crook until they have shorn them exceedingly close.

Dickens is describing Mr. Tulkinghorn's office a moment before his murder but the grimness of the social satire is so intense that we almost lose sight of the dramatic situation. The concentrated wit and the symbolic force of this comment only reveal themselves, after a moment's consideration. The pun on the word "stop," for 
instance, links it with John Jarndyce's earlier image of the Chancery case as a country dance transformed into frantic orgy. And what appears to be a worn colloquialism - the use of the cant phrase "by hook and by crook"-yields its full impact only when we realize that, after all, crooks are appropriate to shepherds, and then grasp the fact that the traditional protective instrument has been turned into a symbol of legal chicanery.

Pastoral detail does not only occur in the descriptive passages in Bleak House. One of the characters uses pastoral imagery constantly to define his view of the world and to comment on the dramatic action. This is Harold Skimpole, who on first appearance describes himself as "very fond of nature, very fond of art." $\mathrm{He}$ seems consequently to escape any easy characterization in the terms of the dialectic of the novel, which defends "natural" sentiment and appears to equate the "artificial" in society with the corrupt; and, indeed, appears by virtue of his wit and fantasy to function as an extra-logical and extra-moral element. We are inclined to regard him merely as an amusing, and even agreeably feckless, critic of society, particularly when he shows himself aware of the element of pure inanity in the Dedlocks, whom he pictures as "stuffed people"- "a large collection, glassy eyed, set up on the most approved manner on their various twigs and perches, very correct, perfectly free from animation, and always in glass cases."

As the novel goes on, however, the dubious aspect of his view of "nature" is fully exposed. One hint lies in the unchanging quality of the world he paints as his imaginative ideal. He wishes to live idly in a world of bees and flowers, like that with which Esther is identified, but one which would have "no spring, autumn, nor winter, but perpetual summer." (Note the contrast here with the emphasis on natural maturity in the Boythorn passage quoted above.) Also, his world is purely escapist; it is a lotus land of rose bowers "with no brambles of sordid realities on its paths." Its corrupt dilettantism becomes clear enough when Skimpole argues that in his eyes the slaves on an American plantation could be accepted as a merely picturesque detail in the scenery. Jo's plight does not 
interest him. Skimpole objects that Jo is too sordidly real; if he were a romantic rebel demanding his rights from society at gunpoint he would be of interest. As it is, his suffering awakens no response.

At one point in the novel Skimpole justifies Chancery by maintaining that its darkness sets off the beauty of the rest of the world. "It may be in the nature of things," he philosophizes, "that A should squint to make B happier in seeing straight." In other words, modern society is so far from the ideal that only a frivolous dilettante seized by a fit of perverse irony can view it with anything but sinking spirits. The plight of Richard Carstone, who has fallen under Skimpole's influence is another source for his selfsatisfaction. Blindly hopeful that wealth will come to him from the settlement of the lawsuit, Richard's morbid suspicion that he is being cheated of his inheritance estranges him from those who love him and have his welfare sincerely at heart. By translating Richard's dreams into pastoral terms Skimpole mocks their unreality at the same time that he characteristically reduces suffering to an aesthetic detail in a picturesque landscape: "This present shepherd, our pastoral Richard, brightens the dull Inns of Court by making Fortune and her train sport through them to the notes of a melodious judgment from the bench. That's very pleasant, you know!"

The source of the satiric detail used in the portrait of Skimpole appears to have been a Christmas book brought out in 1844 by Leigh Hunt, entitled $A$ Jar of Honey from Mount Hybla. It contains a chapter on bees, translations from Theocritus, Bion, and Moschus, and an elaborate celebration of the delights of Sicilian pastoral, and seems to have inspired both Skimpole's amusing disquisition on drones and his taste for bucolic landscape. Skimpole was, of course, widely recognized as a thinly disguised portrait of Hunt by contemporary critics, most of whom objected to the sketch as wildly unjust. Certainly anyone judging Hunt on the basis of his published writings is likely to be considerably puzzled by Dickens's statement that "he is the most exact portrait that was 
ever painted in words." ${ }^{3}$ In fact, the modern reader is more likely to be struck by the Dickensian affinities of Hunt's aesthetic rather than any disparity between the two. Such essays as "Deaths of Little Children" read like a rationale of scenes in Dickens's novels, and Hunt's sentimental, non-metaphysical defense of imagination and fancy might easily have served Dickens as a basis for his attack on calculating utilitarian rationalism in Hard Times. Dickens, despite his protest to the contrary, works largely by exaggeration and exclusion. He takes Hunt's lightest vein, removes the qualifications from his statements, and succeeds in converting a writer of tepid charm into a diabolically scintillating caricature.

Probably the clue to Dickens's animus lies in the symbolism of the three daughters with which he provides Skimpole in Bleak House. Skimpole introduces this picturesquely dishevelled trio to Esther and John Jarndyce as his Comedy daughter, his Sentiment daughter, and his Beauty daughter. The first two might stand allegorically for aspects of Dickens's own art; the third suggests the real discrepancy. Hunt's literary practice-his pretty poems full of nymphs and shepherds and his airy, almost Pollyanna-like optimism-must have struck Dickens as fostering the false taste of those critics, who, from positions of comfort and ease, decried his concern with social evils as morbid and disgusting. Hunt had written in the preface to one of his books of pastoral poems:

Shall we ever have done with begging the question against enjoyment, and denying or doubting the earthly possibility of the only end of virtue itself, with a dreadful wilfulness that prevents our obtaining it? ... The depreciators of this world,- -the involuntary blasphemers of Nature's goodness,- - have tried melancholy and partial systems enough, and talked enough of their own humility. It is high time for them, and for all of us, to look after health and sociality; and to believe, that although we cannot alter the world with an ipse dixit, we need not become desponding, or mistake a disappointed egoism for humility. We should consider ourselves as what we really are,creatures made to enjoy more than to know, to know infinitely nevertheless as we enjoy kindly.... But we persist in being unhealthy, body and mind, and taking our jaundice for wisdom. ${ }^{4}$

\footnotetext{
${ }^{3}$ Letter to Mrs. Watson, Sept. 25, 1853; Louis Landré, Leigh Hunt (1784-1859): Contribution à l'histoire du Romantisme anglais (Paris: Editions «Belles Lettres》, 1936), I, 272.

${ }^{4}$ Foliage: or Poems Original and Translated (London: C. and J. Ollier, 1818), pp. 15-16.
} 
It must be confessed that this is teasingly ambiguous. As a condemnation of the kind of sour-faced piety that afflicts Mrs. Rachel, Dickens would have applauded it. But the further implications of this position, its placid acceptance of the status quo and its hint that the literature of escape is preferable to the literature of social protest because the latter is the product of a diseased mind, would have incensed him. Like T. S. Eliot, Dickens insists that literature must reveal the "boredom and horror" as well as the "glory" of life. He was undoubtedly right in seeing one kind of debased belletrism as a form of defense for the Victorian sensibility in the face of social and moral evil. His specific response in Bleak House is to create a spokesman called "Jarndyce" ("jaundice") and to insist that his highly critical view of society has ample basis in reality.

Skimpole is, at one point, of crucial importance in the plot of Bleak House; it is he who delivers Richard over to the unspeakable Vholes. Dickens does not introduce Vholes until more than half way through the novel, but on his entrance we are suddenly aware that all the forces of darkness, death, and destruction have been concentrated in one symbolic figure. It is not that Mr. Vholes seems particularly threatening in outward appearance or manner. Skimpole recommends him as a paragon of "common sense, responsibility, and respectability," and Conversation Kenge describes him as "diligent, persevering, steady, acute in business." At one moment he seems actually to be the personification of all the Victorian virtues. He is an exemplary family man who protests that he would prefer to retire to the country and that he pursues his legal practice only for the sake of his three daughters and his "aged father in the Vale of Taunton." His professional ethics also appear, on the face of it, unimpeachable: far from encouraging Richard's hopes he affects to be dampening them. But he is fully aware that he need bait no lures, but only give Richard's dementia free play to involve him in self-destruction.

Only when we weigh the symbolism and the ironic comment with which Dickens frames the character does his real nature be- 
come evident. He is represented, for instance, as owning a gig drawn by "a gaunt pale horse." The "pale horse" suggests death (Rev. 6, 8), the gig, coupled with Dickens's reiterated reference to Mr. Vhole's respectability, recalls Carlyle's "respectability with its thousand gigs." His relation to the social system is made clear when Kenge argues that reform of the legal system is unthinkable, since it would jeopardize the livelihood of men like Vholes. Dickens replies that one might just as soon defend cannibalism on the grounds that it is essential to the welfare of cannibals. The analogy sounds merely like a clever debater's point, but Dickens adds to the horror by taking up the idea and developing it. Vholes, we discover, is incapable of enjoying life because he suffers from an "impaired digestion," his office is full of blue bags that look like "gorged serpents," and later he seems to Esther to be making a lingering meal of Richard with his eyes.

A "vole" is a field mouse, and Vholes's name consequently evokes the image of a parasite that destroys crops. "Voling" also means making a clean sweep of the board at cards, an action suggestive of the thoroughness with which he mulcts his clients. Two considerations, however, make it likely that the first association is the primary one. First, Vholes is connected with sterility and the blighted landscape through Esther's curious fantasy on the subject of his trip to St. Alban's. She thinks of his long, thin shadow "on the outside of the coach, passing over all the sunny landscape between us and London, chilling the seed in the ground as it glided along." Moreover, he is repeatedly described in terms of animal imagery. "Quite still, black gloved and buttoned up" he seems to be "looking at his prey and charming it." Later he is likened to an industrious fox or bear "making up his account of chickens or stray passengers for his cubs." His quintessential nature makes him a point of focus for all the evil forces in the book: the fact that his office smells of "unwholesome sheep" relates him to the corrupt shepherd imagery associated with Bulkinghorn; his vampirism to Krook and Smallweed. But it is the death symbolism that predominates and leaves the most powerful impression. When Dickens 
describes him as "making hay of the grass which is flesh, for his three daughters," we are fully prepared for the identification of Vholes with the conventional archetype of death in a pastoral setting: the grim reaper.

It is through the incidental descriptive imagery, through Dickens's satiric commentary on the story, and, above all; through our response to symbolic figures like Vholes that the full meaning of Bleak House is communicated to us. Situations develop, events take place, but there is hardly a formal action, in the classical sense of the word, to unify them. Instead there is a tangled mesh of subplots and minor intrigues; when Dickens wants to heighten the dramatic interest he uses the most inorganic of all narrative techniques, that of detective fiction. Even individual events are likely to be calculated surprises rather than the results of cause and effect relationships within a naturalistic framework. Krook's death by "spontaneous combustion" is purely symbolic. (Dickens neatly associates the idea of "spontaneous combustion" with legal trickery in the preface. The argument runs: Spontaneous combustion does occur; otherwise courts must have erred in their decisions, and this is unthinkable.)

The end of the lawsuit is similarly abrupt and anti-climactic, this time for satirical rather than symbolic reasons. Just as the newly discovered will is about to be probated the lawyers reveal the embarrassing truth: the suit has ended because the estate has been absorbed in costs. We expect a withering comment from Dickens on the monumental futility of such proceedings, but instead his satire modulates into its lightest and broadest tone as the complacent Kenge pronounces a panegyric on the court's handling of the case in which Dickens has him use the novel's fertility symbols for a superbly ironic effect:

\footnotetext{
"You are further to reflect, Mr. Woodcourt," [returned Mr. Kenge] becoming dignified almost to severity, "that on the numerous difficulties, contingencies, masterly fictions, and forms of procedure in this great cause, there has been expended study, ability, eloquence, knowledge, intellect, Mr. Woodcourt, high intellect. For many years, the-a-I would presume to say the flower of the Bar, and the-a-I, would presume to add, the matured fruits of
} 
the Woolsack-have been lavished upon Jarndyce and Jarndyce. If the public have the benefit, and if the country have the adornment, of this great Grasp, it must be paid for in money or money's worth, sir."

The pastoral symbolism of Bleak House takes on three forms: the ideal world of Esther and Boythorn, the sinisterly corrupt one of London law and finance, and the false idealizations of Skimpole's poetic reveries. If one were to look for traditional literary analogues, the ones that would probably come to mind would be Milton's Eden (as an archetype of domestic bliss in a setting of rich natural abundance), the satire of "Lycidas," and finally some such conception as Marlowe's "Passionate Shepherd," a good example of a mock-innocent manner that invites the reader to a willed evasion of "sordid realities." Dickens's technique as a satirist is to play these "realities" and "idealities" against each other for the sake of ironic contrast, as the above quotation demonstrates. The domestic nature of Dickens's ideal is worth further emphasis. It is this which distinguishes Dickens from satirists who chose as their norm some model of heroic moral or intellectual virtue (Swift's Houhynhnms and Shaw's Ancients would be examples) and expose the reader to the contemptuous stare of the superman. Dickens's norm remains a lower-middle-class one, which may explain why, even more than most satirists, he succeeds brilliantly in exposing social incongruities through satiric effects that are witty, poignant, or grotesquely horrifying and is least successful when he tries to make his good people act in a positive fashion, as in the very dull final section dealing with the courtship of Esther.

Bleak House is nevertheless a great work of satiric art, and much of its vitality and power comes from these subtly developed tensions between the real and the ideal. The natural profusion surrounding Boythorn's cottage may seem incredible-we realize that Dickens is here stretching the limits of realistic fiction to touch those of poetry and visionary art-but the poetic excess is that much more effective in satirizing the repulsiveness of London and the law courts. Nor, however absurd this pastoral paradise may appear to 
the cold light of reason, is Dickens willing to grant any further degree of "reality" in the time-hallowed procedures of law and commerce. Kenge's speech, for instance, exposes him as a selfdeluded comic narcissist, and the system he praises as a tissue of artificialities and inconsistencies. Such realities, Dickens implies, are themselves fantastic, and Krook's death symbolizes the holocaust that threatens any society so riddled with internal contradictions.

The question-"What is fantastic, what is real?"-teases the reader of Bleak House as it teases the reader of Kafka. Dickens emphasizes the fantastic deformation of society on his opening page when he compares modern London to the world at the time of the Flood and remarks that "it would not be wonderful to meet a Megalosaurus, forty feet long or so, waddling like an elephantine lizard up Holborn Hill." The introduction of Leviathan in a comic guise should not startle any reader who has carefully digested the book's meaning. If the reference to a "Megalosaurus" calls to mind current paleotological research, it also suggests that the social system it symbolizes is itself an anachronism hopelessly indifferent to human necessity and ridiculously out of touch with the times, and that a new "flood" is dangerously imminent (Chesney Wold is constantly being threatened, both figuratively and literally, by rising waters). Such a symbol, read in the context of the novel as a whole, not only has a satiric force of its own, it also points directly to the dramatic antithesis of the monstrous and humane that is central to it. Only the art of fantasy, Dickens seems to be saying, can do justice to a state of affairs in which social relationships are so perverted by ghoulish greed and outward precedent, and by freeing the reader from the delusion that the absurd is the necessary, restore him to freedom and sanity. 